\title{
The Efficiency of Mitochondria-Targeted Curcumin in Reducing Thyroid Mitochondrial Oxidative Damage
}

\author{
Arun Kumar ${ }^{1}$, Payal Mahobiya ${ }^{2}$ \\ Microbiology and Neuroendocrine Lab, Department of Zoology, School of Biological Sciences \\ Dr. Harisingh Gour Central University Sagar, M.P. India 470003
}

\begin{abstract}
Mitochondria are the crucial site for the cellular energy production. The antioxidant has less therapeutic success to overcome mitochondrial toxicity produced by oxidative stress due to mitochondrial inability in accepting antioxidant. In the present investigation, we synthesized selective mitochondrial targeted curcumin for easy transport to mitochondria of the thyroid gland. Our observation shows the strong antioxidant effect of mitochondrial targeted curcumin against lipid peroxidation and mitochondrial transition induced by Escherichia coli. Mitochondria-targeted curcumin significantly improved endogenous glutathione level in the mitochondria, its protect the motochondrial defense system against oxidative damage. Thus it is concluded that mitochondria-targeted curcumin protects mitochondria against E.coli toxicity of thyroid gland, By lowering the oxidative damage, increasing the level of reduced glutathione and preserving the mitochondrial integrity.
\end{abstract}

Keywords: Mitochondria, mitochondria-targeted curcumin, reactive oxygen species, oxidative stress, membrane permeability transition

\section{Introduction}

The thyroid gland and its associated hormones T3, T4 play an essential role in controlling the body's metabolic activity, development and antioxidant defenses (1-3). Alterations in the normal levels of T3, T4 cause clinical abnormalities and biochemical dysfunctions are to affect mitochondrial respiration producing free radicals (4-6), specially $\mathrm{OH}(7,8)$. Thyroid activity was depressed when bacterial exotoxins injected in mice, rats, and rabbit (9).

Mitochondria plays a vital role in a number of important metabolic activities like amino acid biosynthesis, fatty acid oxidation, lipid metabolism, homeostasis of steroid hormones, urea cycle, apoptosis and intermediate metabolic pathways (10). The mitochondrial dysfunction leads to an alteration in energy metabolism and more generation of reactive oxygen species (ROS) (11). Abnormally high level of ROS may increase lipid peroxidation (LPO), damage to nucleic acid and oxidized necessary proteins, thus leading to damage cellular organelles. One of the most efficient ways to reduce the oxidative damage is to use compounds, which has antioxidant property. Although several conventional non-enzymatic antioxidants such as vitamin-E and vitamin$\mathrm{C}$ have little or less protective value $(12,13)$. One of the potential explanations for this response may be antioxidant therapies has non-specific nature $(14,15)$. Consequently, antioxidants show limited potential and they may not accumulate in sufficient amount inside the mitochondria to reduce oxidative damage. Thus, efficient mitochondrial targeted antioxidants need to develop which have higher permeability towards mitochondrial membrane (16-19).

However, some of the studies have been demonstrating that bacterial cell and their metabolic product present in the extraneous environment of the host might influence thyroid function (20). Escherichia coli produced antithyroid compounds in cell-free and broth cultures (21-23), Paracolon Bacillus has to produce an enzyme that converts progoitrin to goitrin (24). E.coli and Cholera produced an enterotoxin that stimulates cyclic AMP in the thyroid gland and produced antithyroid compound (25).

The naturally occurring Curcuma longa (turmeric) have major phenolic compound curcumin which is a powerful immunomodulatory agent which has anti-inflammatory, antioxidant, anti-cancerous, anti-amyloid and food preservative properties (26-28). The curcumin 1 to $5 \mathrm{gm} / \mathrm{kg}$ of body weight do not cause any adverse effect (29) and long-term administration of curcumin to rodents leads to hyperproliferation of thyroid epithelial cells (30). The present study is to evaluate the level of oxidative damage and the level of the entire key antioxidant enzyme in mice thyroid gland induced by E.coli. We also report the protective effects of curcumin on the thyroid gland of mice.

\section{Materials and Methods}

\section{Chemicals and reagents}

All the following chemicals were of analytical grade supplied by Merck, Hi-Media, and Sigma chemical Co. USA. Triphenylphosphonium oxide (TPP), $\mathrm{HCl}, 48 \%$ Hydrobromic acid (HBr), ethyl acetate, ethanol, dimethosulpho-oxide (DMSO), GSH (Glutathione reduced), riboflavin, Phenazine methosulphate (PMS), lithium lactate, $\mathrm{H}_{2} \mathrm{O}_{2}(30 \%)$, NADH, NADPH, thiobarburetic acid (TBA), trichloroacetic acid (TCA), nitroblue tetrazolium (NBT).

Animal protocol and design

Female adult Swiss albino mice weighing 28-32 gm were obtained from the college of veterinary sciences and animal husbandry Mhow $\left(22.55^{\circ} \mathrm{N}, 75.75^{\circ} \mathrm{E}, \mathrm{M} . \mathrm{P}\right)$, India. The Ethical approval was taken from ADINA Institute of Pharmaceutical Sciences (Registration No. 1546/PO/E/S/11/CPCSEA), Sagar (23.88 N, 78.73 E) with international guidelines for care and use of laboratory animals. All animals $(n=30)$ were housed at $25 \pm 2^{\circ} \mathrm{C}$ with $12 \mathrm{~h}$ light and dark cycle. The whole animals were divided into three groups and each group consists of ten mice. E.coli 


\section{International Journal of Science and Research (IJSR) \\ ISSN (Online): 2319-7064}

Index Copernicus Value (2015): 78.96 | Impact Factor (2015): 6.391

culture was obtained from Institute of Microbial Culture Chandigarh India (MTCC- 68).

\section{Experimental Design}

\section{Synthesis of targeted antioxidant}

Mitochondrial targeted curcumin synthesized by covalent linkage of curcumin with lipophilic cation. TPP (1.31 gm) reacted with $\mathrm{HBr}(350 \mathrm{ml})$ precursor to obtain lipophilicity (31). To synthesize the targeted derivative of curcumin, a solution of lipophilic cation refluxed with curcumin and evaporated to obtained mitochondrial targeted curcumin (mtc) (32).

\section{In vivo study}

Reverse osmosis (RO) water $200 \mu \mathrm{l}$ in $\left(5 \times 10^{6}\right)$ E.coli, and DMSO $(2 \% \quad \mathrm{v} / \mathrm{v})$ (33) were injected in mice by intraperitoneal, after three days $100 \mu \mathrm{mt}-\mathrm{c}(0.12 \mathrm{mg} / 100$ $\mu \mathrm{l})$, RO water and DMSO were induced in mice for seven days. Control group mice for each experimental setup were given simultaneously RO water and DMSO. The animals were euthanizing by decapitation for ten days from treatment. Thyroid gland with trachea was dissected out, washed in ice-cold saline $(0.9 \% \mathrm{NaCl})$, and stored frozen at $80^{\circ} \mathrm{C}$ for further studies.

\section{Preparation of tissue extract}

Thyroid gland extract was prepared in $0.02 \mathrm{M}$ tris- $\mathrm{Cl}(\mathrm{pH}$ $7.4)$ and homogenate $(10 \% \mathrm{w} / \mathrm{v})$. Homogenate was centrifuged at $1000 \mathrm{rpm}$ for $10 \mathrm{~min}$ at $4^{\circ} \mathrm{C}$. After the first centrifugation, the pellet was discarded and the supernatant fluid was recentrifuged at $12500 \mathrm{rpm}$ for $20 \mathrm{~min}$. So obtained was stored for the study of biochemical assay.

\section{Biochemical estimation}

\section{Protein estimation}

Protein content was measured by the method of (34).

\section{Estimatimation of T3, T4, and TSH}

Detection of T3, T4, and Thyroid stimulating hormone (TSH) measured using ELISA provided by The Calbiotech Inc. (California, USA) (35). All the assay were performed in triplicate.

\section{Assay of lipid peroxidation \\ Lipid peroxidation was determined by the measuring of thiobarbituric acid reactive substance (TBARS) in terms of malonaldehyde (MDA) following as described the method (36) with some modification. Briefly, $1 \mathrm{ml}$ of the tris-maleate buffer of $\mathrm{pH} 5.9$, and $10 \mu \mathrm{l}$ of the tissue extract was incubated at $37^{\circ} \mathrm{C}$ for 30 minutes. After, $1.5 \mathrm{ml}$ of TBA reagent was added and the mixture was incubated at boiling water $\left(100-120^{\circ} \mathrm{C}\right)$ for $10 \mathrm{~min}$. After cooling at room temperature pyridine: $\mathrm{n}$ butanol $(3: 1, \mathrm{v} / \mathrm{v})$ mixture and $1 \mathrm{~N}$ $\mathrm{NaOH}$ is added. The contents were thoroughly shaken and allowed to stand for 10 minutes. The photometric measurement was carried out at $548 \mathrm{~nm}$ and the level of lipid peroxidation was expressed as nmol MDA/g.}

\section{Assay of SOD and Catalase}

The activity of superoxide dismutase (EC: 1.15.1.1) was determined method (37). The reaction mixture consisted of
$1.2 \mathrm{ml}$ sodium pyrophosphate buffer ( $\mathrm{pH} 8.3,0.052 \mathrm{M}$ ), 300 $\mu \mathrm{M}$ NBT, $186 \mu \mathrm{M}$ PMS, and $0.1 \mathrm{ml}$ suitably diluted tissue extract. The reactions were started by addition of $780 \mu \mathrm{M}$ $\mathrm{NADH}$ at $30^{\circ} \mathrm{C}$ and stopped after $90 \mathrm{~s}$ by the addition of 1 $\mathrm{ml}$ of TCA. The reaction mixture was stirred with $4 \mathrm{ml}$ of $\mathrm{n}$ butanol and allowed to stand for $10 \mathrm{~min}$. The control set without tissue extract run simultaneously. The unit of the enzyme was defined as $50 \%$ inhibition of NBT/min and the activity was expressed as units/mg protein

The Catalase activity (EC: 1.11.1.6) was measured as described (38), with some modification. Briefly, the reaction mixture $1 \mathrm{ml}$ consisted of $0.067 \mathrm{M}$ phosphate buffer $(\mathrm{pH}$ 7.0) and $0.003 \% \mathrm{H}_{2} \mathrm{O}_{2}$. By the addition of diluted tissue extract, the reaction was started and a decrease in absorbance at $240 \mathrm{~nm}$ was recorded for $10 \mathrm{~min}$. The activity of catalase was expressed as $\mu \mathrm{mol}$ of $\mathrm{H}_{2} \mathrm{O}_{2}$ consumed $/ \mathrm{min} / \mathrm{mg}$ protein.

\section{Glutathione reductase assay}

The activity of glutathione reductase (EC: 1.6.4.2) was measured following the method of (39). The reaction mixture $(1 \mathrm{ml})$ containing $0.2 \mathrm{M}$ potassium phosphate buffer ( $\mathrm{pH}$ 7.0), $0.2 \mathrm{mM}$ EDTA, $2 \mathrm{mM}$ oxidized glutathione (GSSG) and $0.2 \mathrm{mM} \mathrm{NADPH}$. The reaction was initiated by addition of $20 \mu \mathrm{l}$ tissue extract and NADPH was recorded as a decrease in absorbance at $340 \mathrm{~nm}$ for $10 \mathrm{~min}$. Nonspecific oxidation of NADPH was calibrated by the absorbance measured in the absence of GSSG. Unit of the enzyme was defined as $\mu \mathrm{mol} \mathrm{NADPH} / \mathrm{min}$ and the activity of the enzyme was expressed as units/mg protein.

\section{Analysis of SOD and glutathione peroxidase by native PAGE}

For SOD tissue extract $40 \mu \mathrm{g}$ protein was loaded in each lane of $10 \%$ native PAGE. After electrophoresis gels were in Coomassie blue staining solution for 30 minutes, after gels were deep in $2.5 \mathrm{mM}$ NBT solution for 20 minutes and gels were deep in specific staining solution of SOD band as describe earlier (40). The staining mixture contains $28 \mu \mathrm{M}$ riboflavin and $28 \mu \mathrm{M}$ TEMED. After 20 minutes incubation in the dark, gels were exposed to fluorescent light to develop achromatic bands against dark blue background corresponding to SOD protein in the gel.

Glutathione peroxidase (EC: 1.11.1.9) was determined by in non-denaturing method as described earlier (41). Tissue extract containing $40 \mu \mathrm{g}$ proteins was loaded in each lane of $10 \%$ non-denaturing PAGE, Gels were incubated in specific staining mixture containing Tris- $\mathrm{Cl}$ buffer $(50 \mathrm{mM}, \mathrm{pH} 7.9)$ $3 \mathrm{mM}$ GSH, $0.004 \% \mathrm{H}_{2} \mathrm{O}_{2}, 1.2 \mathrm{mM}$ NBT, and $1.6 \mathrm{mM}$ PMS. Achromatic bands of GPx activity appeared against the violet blue background. The intensity of bands was quantified by gel densitometry using ImageJ software.

Detection of antioxidant enzymes on the basis of native PAGE, development of enzyme specific bands were confirmed by comparing the results of similarly run the gels stained in the presence and absence of specific substrates. In each PAGE were performed 4-5 times and mean \pm SD of densitometry values of the bands as relative density of control lane from all the gel run were presented with gels photograph.

\section{Volume 6 Issue 1, January 2017




\section{International Journal of Science and Research (IJSR) \\ ISSN (Online): 2319-7064}

Index Copernicus Value (2015): 78.96 | Impact Factor (2015): 6.391

\section{Statistical Analysis}

Results expressed as mean $\pm \mathrm{SD}$ and student $\mathrm{t}$-test was applied for determining the level of significance between controls and treated groups Fisher (42)

\section{Results and Discussion}

The level of T3, T4 decrease significantly $(p<0.002$, $p<0.01)$ after E.coli exposure compared with control group and increased significantly $(p<0.01, p<0.02)$ in the mt-c treated group compared with E.coli treated group. However, the TSH level increased significantly $(p>0.001, p<0.002)$ in both E.coli and mt-c treated group compared with the control group but decreased significantly $(p>0.001)$ in mt-c treated group compare with E.coli treated group (Histogram 1)

The results of the effect of curcumin on oxidative toxicity induced in thyroid gland are presented in histogram 2. It is clear from the results that $E$. coli administration led to a significant $(p<0.001)$ increase in MDA $(34.30 \pm 0.11 \mu \mathrm{M})$ as compared to control. Upon supplementation of $\mathrm{mt}-\mathrm{c}$ for 7 days to mice, we observed a significant $(p<0.001)$ decrease in MDA concentration $(24.04 \pm 0.07)$ of the thyroid gland when compared with $E$. coli treated group.

The results clarified inhibition on lipid peroxidation by mt-c. The activity of SOD decreased significantly $(p<0.05)$ in thyroid gland when the exposed of $\mathrm{mt}-\mathrm{c}$, whereas SOD activity, increased significantly $(p>0.002)$ when exposed to E.coli through the injection (Histogram 3).

The activity of non-enzymatic antioxidant GSH is most abundant thiol that an important major reducing agent against oxidative damage. As shown in (Histogram 4), the bacterial treatment caused a significant $(p>0.05)$ decrease in GSH level as compared to control. However, treatment of mt-c increased GSH level significantly $(p>0.05)$ in the thyroid gland.

The activity of catalase increase significantly $(p<0.02)$ when the exposed with E.coli, whereas its activity decreased significantly $(p>0.05)$ when exposed with mt-c orally (Histogram 5).

The first step of neutralization of $\mathrm{O}_{2}$ is completed by synchronized activity of SOD and GPx in mice cell. As compared to control group of mice, the enzyme activity of SOD was observed to be increased significantly $(p<0.001)$ when treated with E.coli, whereas its value decreased significantly $(p<0.01)$ in the thyroid gland (Histogram 6, and 7).

In mammalian tissues, four types of GPx have been reported (43). According to histogram as compared to control lanes all GPx isoform increased slightly $(p<0.001)$ when treated with E.coli, whereas value of GPx was decreased significantly $(p<0.01)$ (Histogram 8and 9)

Generation of free radical causes oxidative damage when exceeds the body's natural antioxidant defense systems and damage deoxyribonucleic acid, lipid, and proteins.
Mitochondria are the major source of ROS and thus it may be an easy target to damage a cell by various oxidants and oxidative metabolism (44-47). One of the most prominent mechanisms to counter the oxidative stress is through the use of effective antioxidants as curcumin (48-51). Curcumin has both phenolic and $\beta$ - diketone functional group shows significant antioxidant and free radical scavenging activities $(52,53)$, and it also enhances the activities of antioxidant enzymes such as SOD, GPx, and catalase (54). In the mitochondria, curcumin reduced ROS and prevent oxidative damage, To enhance the efficacy of curcumin against ROS in mitochondria. We synthesized mt-c by conjugation of curcumin with lipophilic cation TPP and they may be rapidly entered in the mitochondria and reduce oxidative stress and mitochondrial impairment. The mt-c is conjugated anionic compound which passes easily through mitochondrial membrane. The E.coli of respiratory chain is an important source for reactive oxygen species (ROS), and mutants in the cytochrome oxidase complex of E.coli have increased ROS levels, as well as increased sensitivity to exogenous oxidative stress (55). We consider the possibility that microbial ROS may induce a mitochondrial stress response.

Curcumin interact with ROS by scavenging or neutralizing free radicals, inhibiting LPO and maintain cell membrane integrity and their function (56). The lipid peroxides are presumptive markers of oxidative damage(57), so we tested first the effect of E.coli on thyroid mitochondria. Our results showed a significant increase in the LPO by E.coli treatment. After the treatment of $\mathrm{mt}-\mathrm{c}$, it's a significant decrease. The present study shows the efficacy of mt-c to reduced LPO induced by E.coli. Curcumin was also found to ameliorate indomethacin drug induced LPO in mitochondria isolated from the small intestine.

Tha level of reduced glutathione (GSH), a tripeptide ( $\mathrm{L}-\gamma-$ glutamyl-L-cysteinyl glycine) responsible for maintaining reducing equivalents under oxidative stress, another critical factor is assessing the level of oxidative stress in mammalian cells(58). Mitochondrial GSH also has an important role in the maintain the mitochondrial integrity(59). The level of GSH under stress condition have been depleted can increase mitochondrial damage and cause a defect in mitochondrial energy conservation (60). In the present study, E.coli treatment caused a significance decrease of GSH in the mitochondria. After treatment of mt-c, its significant increase the level.our observation is clearly showing the effectiveness of mt-c defending the mitochondria from lethal effect of oxidative stress.

The excess of superoxide anion $\left(\mathrm{O}_{2}^{-}\right)$, is maximum, produced ROS in mitochondria is converted to $\mathrm{H}_{2} \mathrm{O}_{2}$ by SOD. Simultaneous $\mathrm{H}_{2} \mathrm{O}_{2}$ is removed by either catalase/GPx, these are crucial for preventing membrane damage due to oxidative stress. In thyroid gland, SOD-GPxGR pathway is considered to play a major role of antioxidant activity(61), with the increased level of ROS after the treatment of E.coli, is significantly increased GPx, SOD, and catalase and ameliorate with mt-c it's a significant decrease.

The investigation of SOD and GPx by native PAGE its activity significantly increase with the treatment of E.coli 


\section{International Journal of Science and Research (IJSR) \\ ISSN (Online): 2319-7064}

Index Copernicus Value (2015): 78.96 | Impact Factor (2015): 6.391

and after amelioration with mt-c its significantly activity decrease.

\section{Conclusion}

In conclusion, the present study professed that the mt-c will be able to reduce oxidative damage in mitochondria of the thyroid gland against bacterial toxicity. This study will provide additional information on the role of free radical and biochemical changes in the mt-c treated mice.

\section{Acknowledgment}

AK thanks, Dr. Harisingh Gour Central University, Sagar for providing non-NET research fellowship. The authors are also grateful to Department of Zoology, Dr. Harisingh Gour Central University, Sagar, for providing infrastructural facilities and constant support.

\section{References}

[1] Griffen JE. The thyroid. In Textbook of Endocrine Physiology ed. Griffen, J.E., and Ojeda, S.R.1996; 260283. New York, NY: Oxford University Press.

[2] Das K, Chainy GBN. Thyroid hormone influences antioxidant defense system in adult rat brain. Neurochem Res.2004; 29:1755-1766

[3] Kundu S, Pramanik M, Roy S, De J, Biswas A, Ray AK. Maintenance of brain thyroid hormone level during peripheral hypothyroid condition in adult rat. Life Sci. 2006; 79:1450-5.

[4] Mano T, Sinohara R, Sawai Y. Effects of thyroid hormone on coenzyme $\mathrm{Q}$ and other free radical scavengers in rat heart muscle. J Endocrinol.1995; 145:131-136.

[5] Katyare SS, Rajan RR. Influence of thyroid hormone treatment on the respiratory activity of cerebral mitochondria from hypothyroid rats. A critical reassessment. Exp Neurol 2005; 195:416-22.

[6] Jezek P, Hlavata' L. Mitochondria in homeostasis of reactive oxygen species in cell, tissues, and organism. Int J Biochem Cell Biol 2005; 37:2478-503.

[7] Poncin S, Gérard AC, Boucquey M, Senou M, Calderon PB, Knoops B, Lengelé B, Many MC, Colin IM: Oxidative stress in the thyroid gland: from harmlessness to hazard depending on the iodine content. Endocrinology 2008, 149:424-433.

[8] Poncin S, Van Eeckoudt S, Humblet K, Colin IM, Gérard AC: Oxidative stress: a required condition for thyroid cell proliferation. Am J Pathol 2010, 176:13551363.

[9] Gerwing J, Long DA, Pitt-Rivers R. The influence of bacterial exotoxins on the activity of the thyroid gland in different species. J. Physiol.1958; 144:229-242.

[10] Schon EA, Manfredi G. Neuronal degeneration and mitochondrial dysfunction. J Clin Invest. 2003; 111:303-312.

[11] Cassarino DS, Bennett JP, Jr. An evaluation of the role of mitochondria in neurodegenerative diseases: mitochondrial mutations and oxidative pathology, protective nuclear responses, and cell death in neurodegeneration. Brain Res Brain Res Rev.1999; 29:1-25.

[12]Bjelakovic G, Nikolova D, Gluud L.L, Simonetti RG, Gluud C. Antioxidant supplements for prevention of mortality in healthy participants and patients with various diseases. Cochrane Database Syst.2008; Rev: CD007176.

[13] Cocheme HM, Murphy M.P. Can antioxidants be effective therapeutics? Curr Opin Investig Drugs.2010; 11:426-431.

[14] Murphy MP, Smith RA. Drug delivery to mitochondria: the key to mitochondrial medicine. Adv Drug Deliv Rev.2000; 41:235-250.

[15] Murphy MP, Smith RA. Targeting antioxidants to mitochondria by conjugation to lipophilic cations. Annu Rev Pharmacol Toxicol.2007; 47:629-656.

[16] Smith RA, Porteous CM, Coulter CV, Murphy MP. Selective targeting of an antioxidant to mitochondria. Eur J Biochem.1999; 263:709-716.

[17] Szeto HH. Mitochondria-targeted cytoprotective peptide for Ischemia- repefusion injury. Antioxid Redox Signal.2008; 10:601-619.

[18] Skulachev VP, Anisimov VN, Antonenko YN, Bakeeva LE, Chernyak BV, Erichev VP, Filenko OF, Kalinina NI, Kapelko VI, Kolosova NG, Kopnin BP, Korshunova GA, Lichinitser MR, Obukhova LA, Pasyukova EG, Pisarenko OI, Roginsky VA, Ruuge EK, Senin II, Severina II, Skulachev MV, Spivak IM, Tashlitsky VN, Tkachuk VA, Vyssokikh MY, Yaguzhinsky LS, Zorov DB. An attempt to prevent senescence: a mitochondrial approach. Biochim Biophys Acta.2009; 1787:437-461.

[19] Jat D, Parihar P, Kothari SC, Parihar MS. Curcumin reduces oxidative damage by increasing reduced glutathione and preventing membrane permeability transition in isolated brain mitochondria. Cell Mol. Biol. (Noisy-le-grand). 2013; 59:1899-905.

[20] McCarrison R. In Commission suisse de goitre, Comptes-rendus de la Conference Internationale du Goitre Berne 24-26 Aout 1927, Hans Huber, Berne, 1928, p. 304 (Report of 1st International Goiter Conference).

[21] London WT, Koutras DA, Pressman A, Vought RL. J Clin Endocrinol Metab.1965; 25: 1091.

[22] Vought RL, London WT, Stebbing GET. J Clin Endocrinol Metab.1967; 27: 1381.

[23] Malamos B, Koutras DA, Rigopoulos GA, Papapetrou PD, Gougas E, Kelperi H, Moraitopoulos C, Davi E, Leonardopoulos J. Clin Endocrinol Metab.1971; 32:131.

[24] Oginsky EL, Stein AE, Greer MA. Proc Soc Exp Biol Med.1965; 119:360.

[25] Mashiter K, Mashiter GD, Hauger RL, Field JB, Endocrinology.1973; 92:541.

[26] Chopra RN, Chopra TX, Honda KL, Kapoor LD. Chopra's Indigenous Drugs of India, U.N. Dhar and Sons Pvt. Ltd., Calcutta.1958.

[27] Subudhi U, Das K, Paital B, Bhanja S, Chainy GBN Supplementation of curcumin and vitamin E enhances oxidative stress, but restores hepatic histoarchitechture in hypothyroid rats. Life Sci.2009; 84:372-379.

[28] Jena S, Chainy GBN. Regulation of expression of antioxidant enzymes by vitamin $\mathrm{E}$ and curcumin in Lthyroxine induced oxidative stress in rat renal cortex. 


\section{International Journal of Science and Research (IJSR) \\ ISSN (Online): 2319-7064}

Index Copernicus Value (2015): 78.96 | Impact Factor (2015): 6.391

Mol Biol Rep.2011; 38:1047-1054.
doi:10.1007/s11033-010-0201-4

[29] Lilia HS, Hagopian M, Esber HJ, Fleischman RW, Russfield AB, Tiedmann KM. Report on the subchronic toxicity by dosed feed of turmeric oleoresin in Fischer 344 rats and B6C3F1 mice. EGG Mason Research Institute.1983; Report no. MRI-NTP 11-83-22. Available: http:/www.inchem.org/ documents/jecfa/jecmono/v21je06.htm.

[30] Hardisty JF, Lilja HS, Smith SL. Toxicology and carcinogenesis studies of turmeric oleoresin in 344/N rats and B6C3F1 mice. Natl Toxicol Program Tech Rep Ser. 1993; 427:1-275.

[31] Hercouet A, Le Corre M. Synthesis.1988; 157.

[32] Smith RAJ, Carolyn MP, Gane AM, Murphy MP. Delivery of bioactive molecules to mitochondriainvivo.Proc.Natl.Acad.Sci.2003;100(9):54 07-5412. doi:10.1073/pnas.0931245100

[33] Kunwar A, Barik A, Pandey R, Priyadarsini KI. Transport of liposomal and albumin loaded curcumin to living cells: an absorption and fluorescence spectroscopic study. Biochim Biophys Acta.2006; 1760:1513-1520.

[34] Lowry OH, Rosebrough NJ, Farr AL, Randall RJ. Protein measurement with the Folin phenol reagent. J Biol Chem.1951; 193:265-275.

[35] Sachidhanandam M, Singh SN, Salhan AK, Ray US. Evaluation of plasma hormone concentrations using enzyme-immunoassay/enzyme-linked immunosorbent assay in healthy Indian men: effect of ethnicity. Indian J Clin Biochem. 2010; 25:153-157.

[36] Placer ZA, Cushman LL, Johnson BC. Estimation of product of lipid peroxidation (malonyl dialdehyde) in biochemical systems. Anal Biochem.1966; 16: 359364.

[37] Kakkar P, Das B, Viswanathan PN. A modified spectrophotometric assay of superoxide dismutase ( SOD). Ind J Biochem Biophys. 1984; 21:130-132.

[38] Luck H. Catalase. In, methods of enzymatic analysis. (Ed.Begmeyer HU) Academic press, Newyork.1963; 895-897.

[39] Carlberg I, Mannervik B. Purification and characterization of the flavoenzyme glutathione reductase from rat liver. J Biol Chem.1975; 250:54755480.

[40] Beauchamp C, Fridovich I. Superoxide dismutase: improved assays and an assay applicable to acrylamide gels. Anal Biochem.1971; 44:276-287.

[41] Lin CL, Chen HJ, Hou WC. Activity staining of glutathione peroxidase after electrophoresis on native and sodium dodecyl sulfate polyacrylamide gels. Electrophoresis.2002; 23:513-516.

[42] Fisher RA, Yates F. Satatistical Tables. London, Oliver and Boyed. 1953.

[43]Flohe RB. Tissue-specific function of individual glutathione peroxidases. Free Radical Biol Med.1999; 27:951-965.

[44] Loschen G, Flohe L, Chance B. Respiratory chain linked $\mathrm{H} 2 \mathrm{O} 2$ production in pigeon heart mitochondria. FEBS Lett.1971; 18:261-264.

[45] Boveris A, Oshino N, Chance B. The cellular production of hydrogen peroxide. Biochem J.1972; 128:617-630.
[46]Chance B, Sies H, Boveris A. Hydroperoxide metabolism in mammalian organs. Physiol Rev.1979; 59:527-605.

[47] Raha S, Robinson BH. Mitochondria, oxygen free radicals, disease and ageing. Trends Biochem Sci.2000; 25:502-508.

[48] Balogun E, Hoque M, Gong P, Killeen E, Green CJ, Foresti R, Alam J, Motterlini R. Curcumin activates the haem oxygenase- 1 gene via regulation of $\mathrm{Nrf} 2$ and the antioxidant-responsive element. Biochem J.2003; 371: 887-895.

[49] Duvoix A, Blasius R, Delhalle S, Schnekenburger M, Morceau F, Henry E, Dicato M, Diederich M. Chemoprotective and therapeutic effects of Curcumin. Cancer Lett.2005; 223:181-190.

[50] Weber WM, Hunsaker LA, Gonzales AM, Heynekamp JJ, Orlando RA, Deck LM, Vander Jagt DL. TPAinduced up-regulation of activator protein-1 can be inhibited or enhanced by analogs of the natural product curcumin. Biochem Pharmacol.2006; 72: 928-940.

[51] Jena S, Chainy GBN, Dandapat J. Expression of antioxidant genes in renal cortex of PTU-induced hypothyroid rats: effect of vitamin E and curcumin. Mol Biol.2011; Rep doi: 10.1007/ s11033-011-0849-4

[52] Jovanovic SV, Steenken S, Boone CW, Simic MG. Hatom transfer is a preferred antioxidant mechanism of curcumin. J Am Chem Soc.1999; 121: 9677-9681.

[53] Weber WM, Hunsaker LA, Abcouwer SF, Deck LM, Vander Jagt DL. Anti-oxidant activities of curcumin and related enones. Bioorg Med Chem.2005; 13: 3811 3820 .

[54] Reddy AC, Lokesh BR. Studies on the inhibitory effects of curcumin and eugenol on the formation of reactive oxygen species and the oxidation of ferrous iron. Mol Cell Biochem.1994; 137:1-8.

[55] Brynildsen MP, Winkler JA, Spina CS, MacDonald IC, Collins JJ. Potentiating antibacterial activity by predictably enhancing endogenous microbial ROS production. Nat Biotechnol.2013; 31(2):160-165.

[56] Balasubramanyam M, Koteswari AA, Kumar RS, Monickaraj SF, Maheswari JU, Mohan V. Curcumin induced inhibition of cellular reactive oxygen species generation: novel therapeutic implications. J Biosci.2003; 28:715-721.

[57] Girotti AW, Thomas JP. Damaging effects of oxygen radicals on resealed erythrocyte ghosts. J Biol Chem.1984; 259:1744-1752.

[58] Meister A, Anderson ME. Glutathione. Annu Rev Biochem.1983;52:711-760.

[59] Mari M, Morales A, Colell A, Garcia-Ruiz C, Fernandez-Checa JC. Mitochondrial glutathione, a key survival antioxidant. Antioxid Redox Signal.2009; 11:2685-2700.

[60] Hoek JB, Cahill A, Pastorino JG. Alcohol and mitochondria: a dysfunctional relationship. Gastroenterology.2002; 122:2049- 2063.

[61] Tureen JF Mitochondrial formation of reactive oxygen species. J Physiol.2003; 552:335-344. 


\section{International Journal of Science and Research (IJSR) ISSN (Online): 2319-7064}

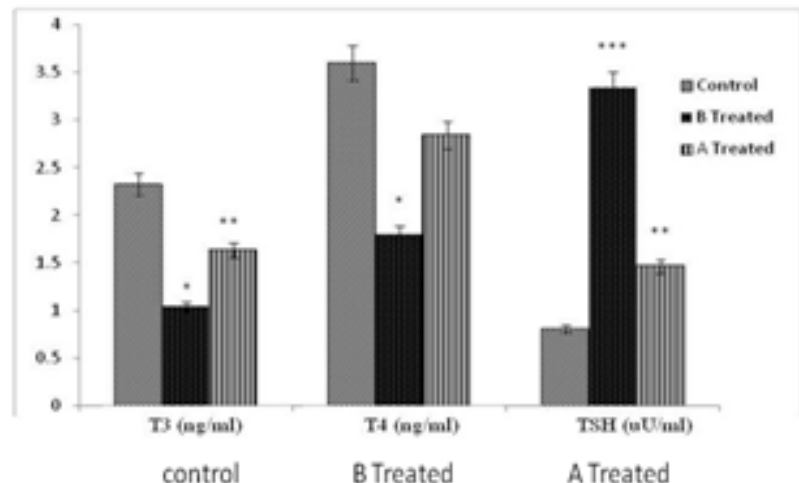

Histogram 1 .Effect of $E$.coli and $m t-c$ on mice serum, hormone levels in the group studied. T3, T4, TSH (Thyroid stimulating hormone). B treated- E.coli treated, Atreated-m-tc treated.

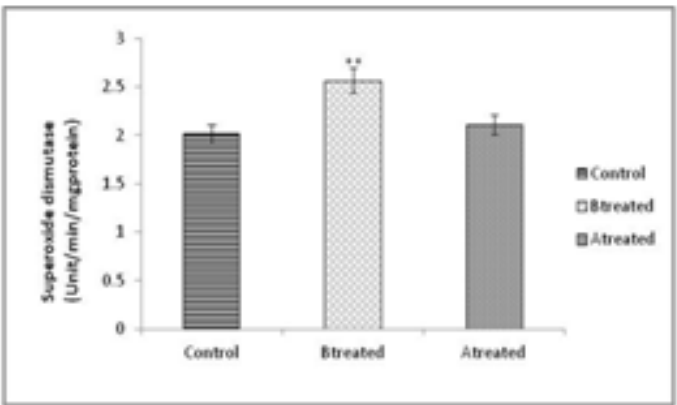

Histogram 3 Effect of E.coli and mt-c on the specific activity of superoxide dismutase on the thyroid gland of mice. data panel represents mean 5 SO from 3.4 oberservation. $p<0.002, p>0.05$ (Control vs. treated group). Btreated-E.coli treated, Atreated-m-tc treated.

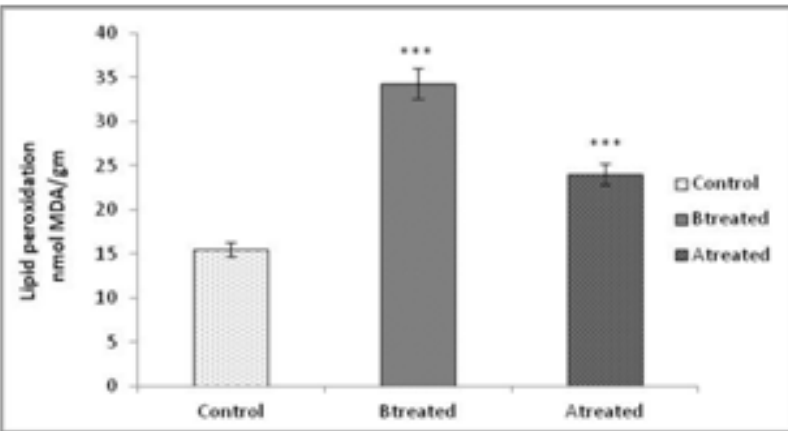

Histogram 2. Effects of E.coli and m-tc, LPO in the thyroid gland. Data in panel represents mean \pm SD from $4-5$ observation. ${ }^{* *} p<0.001$ (control vs treated group).Btreated-E.coli treated, Atreated- $m t-c$ treated.

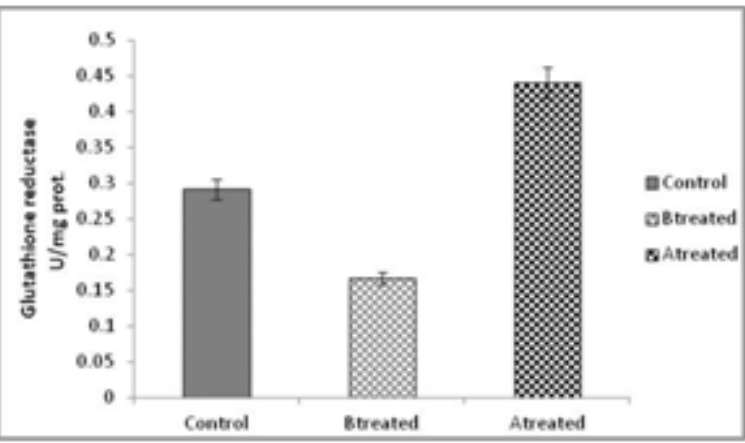

Histogram 4 Effect of E.coli and mt-c on specific activity of glutathione reductase on the thyroid gland of mice. data panel represents meant SD from 3.4 observation. $p<0.05, p<0.05$ (Control vs treated group). B treated-E.coli treated, Atreated- $\mathrm{m}$-tc treated.

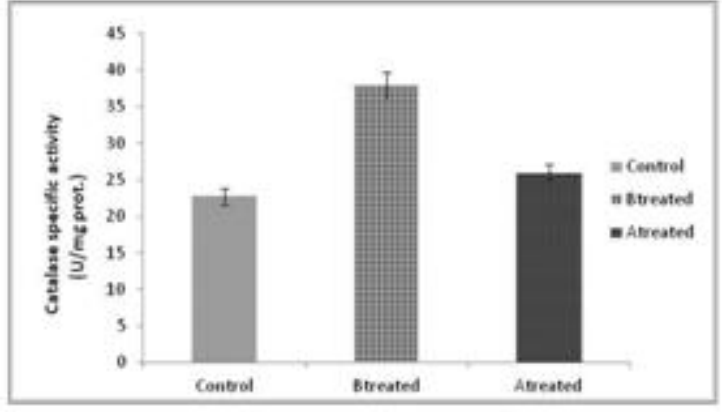

Histogram 5. Effect of E.coli and mt-c on the specific activity of catalase in the thyroid gland. data in panel represents mean $\pm S D$, from 3-4 observation. p<0.02,p>0.05 (Control vs treated group). Btreated-E.coli treated, Atreated-m-tc treated.

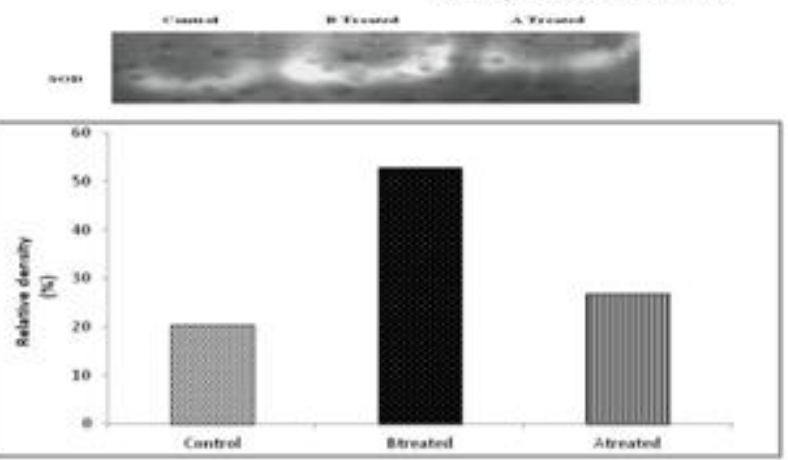

Histogram 6 and 7. Effects of E.coll and m-tc, superoxide dismutase in thyroid gland. Represents relative intensity of SOD band taking three lanes.Btreated-E.coli treated, Atreated- $m t-c$ treated.

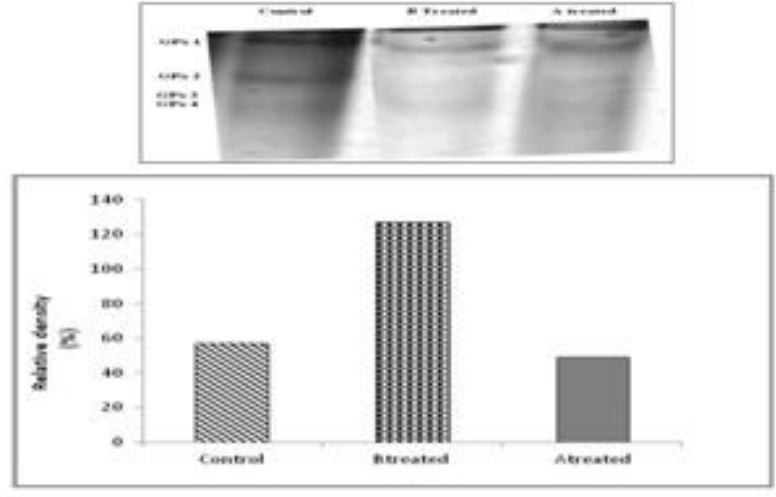

Histogram 8 and 9 . Effects of $E$. coli and $m-t c$, a glutathione peroxidase in thyroid gland. Represents relative intensity of GPx band taking three lanes. Btreated-E.coli treated, Atreated- $m t-5$ treated. 


\section{International Journal of Science and Research (IJSR) \\ ISSN (Online): 2319-7064}

Index Copernicus Value (2015): 78.96 | Impact Factor (2015): 6.391

\section{Author Profile}

Arun Kumar received the B.Sc. (Biotech) from jiwaji University, Gwalior in 2010 and M. Sc. Degree in Microbiology from jiwaji University in 2012. He is currently pursuing Ph.D. in Zoology from Dr. H. S. Gour University, Sagar(India). She has also cleared GATE in life sciences in 2011.

Dr. Payal Mahobiya recived the B.Sc. (Zoology) in 2001, M. Sc. Degree in Zoology in 2003 from Dr. H. S. Gour University, Sagar(India). She has done her $\mathrm{Ph} . \mathrm{D}$. in Zoology from Dr. H. S. Gour University, Sagar(India). Since 2007 she is working as Assistant Professor in Department of Zoology at Dr. H. S. Gour University, Sagar(India). 